\title{
Moffett wins academic/research librarianship's highest honor
}

William Andrew Moffett, director of the Hun- College Libraries Section of ACRL (1984-85). In tington Library in San Marino, California, has 1989-90 he was elected president of the assobeen named the 1993 ACRL Academic/Research Librarian of the Year. Moffett will receive the award $(\$ 3,000$ cash and a citation) at a reception given in his honor on June 28, 1993, during the ALA Annual Conference in New Orleans. The reception immediately follows ACRL's President's Program. Baker \& Taylor Books sponsors the reception and donates the cash award and citation.

In nominating Moffett, his colleagues said, "He has remained at the forefront of academic and research librarians in

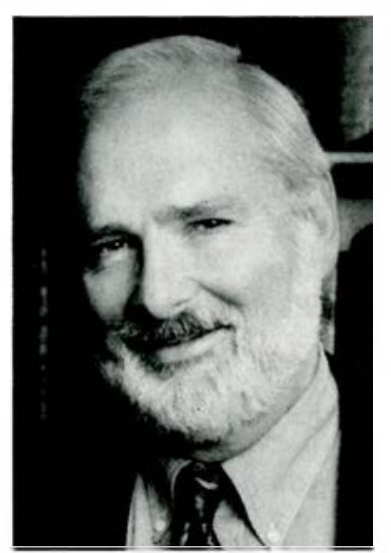

William A. Moffett

ciation. In 1992 the association's Board of Directors recognized Moffett with a special certificate of commendation citing his courage, integrity, and commitment to high standards, as an exemplar of all members of the association for their praise and emulation.

Frequently called upon as a speaker, both within the library profession and without, Moffett's topics have ranged from the poetry of Robert Burns to the iconography of the book in Western art, from conservation issues to automation, from movements whose aims are to preserve and increase the power of our libraries' users. Librarianship has had few leaders who have contributed as much to the profession both within libraries and the scholarly community, and he truly deserves recognition as Academic/Research Librarian of the Year."

In selecting Moffett for the association's highest honor, committee chair Paul Dumont said, "He has demonstrated leadership as an educator, an academic librarian, and a historian.

He embodies the highest standards for the profession." The committee, citing Moffett's leadership in combating the theft of and trade in rare books, and for successfully challenging in 1991 the scholarly monopoly of unpublished Dead Sea Scrolls materials, said, "these contributions have brought both national and international attention to the profession."

Moffett's leadership in organizing the Oberlin Group of Liberal Arts College Libraries while he was director of the Oberlin College Library was also noted by the committee. This organization has brought together a network of 60 libraries with common goals and problems in a way that encourages mutual support on behalf of each member library.

In recognition of his contributions to the profession, Moffett was elected chair of the academic politics to the ethical challenges of librarianship.

Moffett has held academic and administrative appointments in several institutions since beginning his professional career. He taught history at Alma College (Michigan) and the University of Massachusetts at Boston, and has been director of libraries at Potsdam College (SUNY) and Oberlin College. At Oberlin he occupied one of the nation's oldest endowed positions in academic librarianship, the Azariah Smith Root directorship, in which he distinguished himself as a library builder and a spokesperson for college librarians.

The Academic/Research Librarian of the Year Award is given annually to recognize an individual who is making outstanding contributions to academic or research librarianship and library development. Previous winners have included Carla Stoffle (1992); Richard DeGennaro (1991); Patricia Battin (1990); John P. McGowan (1989); Edward G. Holley (1988); Duane Webster (1987); Margaret Beckman (1986); Jessie Carney Smith (1985); Richard D. Johnson (1984); Richard M. Dougherty (1983); William Budington (1982); Beverly P. Lynch (1981); Evan Ira Farber (1980); Henriette D. Avram and Frederick G. Kilgour (1979); Keyes D. Metcalf and Robert D. Downs (1978). 